\title{
PENGARUH SUPLEMENTASI IKAN NILA TERHADAP ASUPAN ANAK DENGAN GIZI BURUK
}

\author{
Darmawansyih*, Andi Faradillah*, Nadyah* \\ *UIN Alauddin Makassar \\ +6281355629311 \\ darmawansyih@uin-alauddin.ac.id
}

\begin{abstract}
Abstrak
Masalah kecukupan gizi yang merupakan masalah klasik yang masih ditemui di Indonesia adalah cakupan ASI eksklusif, stunting pada balita dua tahun (baduta), anemia pada ibu hamil, dan pemantauan pertumbuhan pada balita. Ikan nila merupakan salah satu pangan lokal yang berpotensi menjadi sumber makanan fungsional yang mengandung berbagai asam amino diantaranya gulatamat yang dapat menjadi stimulus peningkatan nafsu makan pada anak yang pada akhirnya dapat membantu perbaikan status gizinya. Asam amino glutamat dapat mempengaruhi kerja otak melalui gut-brain-axis merupakan mekanisme yang dapat mendasari manfaat ikan nila terhadap perbaikan status gizi anak dengan gizi kurang dan gizi buruk.

Penelitian ini merupakan penelitian quasi eksperimental dengan rancangan penelitian uji klinik randomisasi tersamar tunggal untuk mengetahui pengaruh suplementasi kapsul ikan nila terhadap asupan anak dengan gizi buruk. Subyek penelitian sebanyak 42 sampel yang dikelompokkan menjadi dua kelompok yakni kelompok pertama (kelompok intervensi) sebanyak 23 sampel dan kelompok kedua, kelompok kontrol sebanyak 19 sampel. Dari hasil penelitian Pengaruh Suplementasi Kapsul Ikan Nila Terhadap Asupan Anak Gizi Buruk didapatkan tidak ada perbedaan bermakna antara asupan energi dan protein Pre dan post dalam kelompok intervensi dan antar kelompok intervensi dan kelompok kontrol.
\end{abstract}

Kata kunci : Ikan nila, Gizi buruk

\section{Pendahuluan}

Masalah kecukupan gizi yang merupakan masalah klasik yang masih ditemui di Indonesia adalah cakupan ASI eksklusif, stunting pada balita dua tahun (baduta), anemia pada ibu hamil, dan pemantauan pertumbuhan pada balita. Data balita dengan gizi kurang berdasarkan data Riskesdas belum mengalami perbaikan dari tahun 2007 hingga tahun 2013 sebesar 17.9\% sementara kasus stunting masih termasuk tinggi dengan $37.2 \%$ dan angka ini juga tidak menunjukkan perbaikan. ${ }^{1}$

Masalah gizi pada anak perlu menjadi perhatian mengingat Indonesia harus terus memupuk daya saing sumber daya manusia yang dapat berkompetisi di tingkat regional maupun global. Untuk menjawab permasalahan gizi diperlukan kesadaran masyarakat dalam menentukan penyelesaian masalah gizi di lingkungannya terutama terkait dengan pemanfaatan potensi lokal ${ }^{2}$. Keberadaan sumber pangan dan nutrisi yang merupakan potensi lokal dengan harga terjangkau akan sangat membantu masyarakat meningkatkan kualitas gizi. Ikan nila merupakan salah satu pangan lokal yang berpotensi menjadi sumber makanan fungsional. ${ }^{3}$

Beberapa penelitian mengenai komposisi ikan nila melaporkan adanya kandungan berbagai asam amino diantaranya glutamat yang dapat menjadi stimulus peningkatan nafsu makan pada 
anak yang pada akhirnya dapat membantu perbaikan status gizinya. Asam amino glutamat dapat mempengaruhi kerja otak melalui gut-brain-axis merupakan mekanisme yang dapat mendasari manfaat ikan nila terhadap perbaikan status gizi anak dengan gizi kurang dan gizi buruk. ${ }^{4}$

Glutamat memberikan efek menjanjikan mencegah keadaan malnutrisi dengan membantu metabolisme protein dalam sel serta absorpsi makanan dengan lebih cepat dengan mempercepat pengosongan lambung. Hal penting lainnya adalah penggunaan glutamat terbukti dapat memperbaiki nafsu makan dan berdampak pada peningkatan asupan makanan yang pada akhirnya menyebabkan keseimbangan nitrogen yang positif. ${ }^{5,6}$

Sampai saat ini penggunaan suplemen ekstrak ikan nila untuk membantu perbaikan asupan dengan metode pengukuran keseimbangan nitrogen belum pernah dilakukan. Sehingga, melalui penelitian ini bermaksud melihat potensi ikan nila sebagai penambah nafsu makan untuk membantu perbaikan keseimbangan nitrogen pada anak dengan gizi buruk.

Glutamat telah terbukti mengaktivasi kontraktilitas dan aliran darah pada fundus lambung melalui neuron-neuron kolinergik. Laporan lain menunjukkan reseptor glutamat juga terlibat pada pengaturan sekresi asam lambung oleh reseptor inotropik, dan aspartat mengatur sekresi asam pada lambung dengan menghambat pengeluaran histamin melalui reseptor NMDA. Reseptor NMDA memperantarai pengaturan fungsi motorik lambung dan juga mempercepat pengosongan lambung dan asupan makanan. Laporan lain, menunjukkan keterlibatan reseptor ionotropik pada respon vagal mekanosensitif pada antrum gaster ${ }^{4,7}$. Infus glutamat secara spesifik menstimulasi saraf vagal gaster aferen sedangkan asam amino lain tidak. ${ }^{5}$

Islam juga memperhatikan pengobatan baik, yang bersifat kuratif maupun preventif. Islam sangat menghargai bentuk-bentuk pengobatan yang didasari oleh ilmu pengetahuan, penelitian, eksperimen ilmiah dan hukum sebab-akibat.

Keanekaragaman tumbuhan dan binatang yang diciptakan oleh Allah SWT tentu saja tidak sia-sia dan meiliki manfaat. Segala sesuatu yang diciptakan Allah swt memiliki fungsi sehingga dihamparkan di bumi. Salah satu fungsinya adalah bahan pengobatan. Hanya saja untuk mengetahui fungsi dari aneka macam apa yang telah Allah ciptakan diperlukan ilmu pengetahuan dalam mengambil manfaat Di dalam Firman Allah SWT di dalam QS.Al-Syu'arā/26: $7^{8}$ 


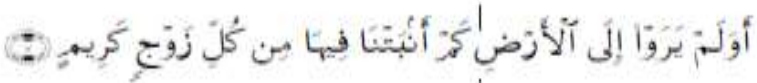

Terjemahnya :

"Dan apakah mereka tidak memperhatikan bumi, berapakah banyaknya kami tumbuhkan di bumi itu pelbagai macam tumbuh-tumbuhan yang baik?"

\section{Bahan dan Metode Penelitian}

Penelitian ini merupakan penelitian quasi eksperimental dengan rancangan penelitian uji klinik randomisasi tersamar tunggal untuk mengetahui pengaruh suplementasi kapsul ikan nila terhadap asupan anak dengan status gizi kurangburuk. Penelitian ini dilakukan di beberapa kelurahan di wilayah Makassar.

Subyek penelitian sebanyak 42 sampel yang diperoleh dari populasi penelitian yang sesuai dengan kriteria penerimaan. Subyek penelitian dikelompokkan menjadi dua kelompok yang menerima perlakuan yang berbeda melalui proses randomisasi tersamar tunggal. Kelompok pertama (kelompok intervensi) sebanyak 23 sampel dan kelompok kedua, kelompok kontrol sebanyak 19 sampel.

Dalam penelitian ini dilakukan penilaian peningkatan skor nafsu makan dengan memperhatikan perbandingan perubahan asupan energi dan protein dalam kelompok kontrol, kelompok perlakukan/intervensi dan antara kelompok kontrol dan kelompok perlakuan/intervensi.
Data didapatkan melalui metode :

Wawancara/anamnesis untuk mendapatkan data identitas, riwayat penyakit dahulu dan sekarang, dan riwayat makanan dengan metode tanya ulang $1 \mathrm{X}$ 24 jam pada subyek penelitian. Wawancara dilakukan dengan menggunakan lembar kuesioner dan alat peraga makanan (food model).

Pengukuran Antropometri untuk mendapatkan berat badan dan tinggi badan. Penilaian asupan makanan dengan metode tanya ulang 1 X 24 jam (one day food recall) dan pencatatan asupan makanan selama penelitian. Tanya ulang 1 X 24 jam dilakukan setiap hari selama 14 hari jangka waktu penelitian.

Data diolah dengan menggunakan Uji Normalitas. Untuk melihat hubungan antar kelompok dilanjutkan dengan kemudian dilanjutkan dengan Uji $\mathrm{T}$ pada data dengan distribusi normal dan Uji Mann Whitney untuk data tidak berdistribusi normal. Untuk melihat hubungan data dalam kelompok dilakukan Uji $\mathrm{T}$ pada data dengan distribusi normal dan Uji Wilcoxon untuk data tidak berdistribusi normal.

\section{Hasil dan Pembahasan}

Dari hasil penelitian Pengaruh Suplementasi Kapsul Ikan Nila Terhadap Asupan Anak Gizi Buruk didapatkan tidak ada perbedaan bermakna antara asupan 
energi dan protein Pre dan post dalam kelompok intervensi dan antar kelompok intervensi dan kelompok kontrol. Walau dari data nampak ada kenaikan angka asupan energi dan protein pre dan post dalam kelompok intervensi, namun secara statistik tidak bermakna.

Asupan dan kecukupan energi merupakan salah satu faktor yang mempengaruhi status gizi ${ }^{9}$ Meskipun beberapa penelitian lain mengatakan bahwa : asupan nutrisi yang salah satunya ikan dapat mempengaruhi status gizi sementara status gizi dapat dipengaruhi oleh asupan energi ${ }^{10}$, terdapat hubungan yang bermakna antara jumlah protein ikan dan pendapatan orang tua dengan status gizi berdasarkan $\mathrm{TB} / \mathrm{U}^{11}$, terdapat hubungan antara konsumsi jenis ikan terhadap kejadian stunting pada anak usia 2-5 tahun $^{12}$. Beberapa penjelasan yang dapat menjadi alasan dari hasil temuan ini adalah jumlah sampel yang minim sehingga dapat mempengaruhi data secara statistik; sampel penelitian berupa anak 25 tahun yang mana asupan makanannya masih sangat tergantung pada ibu/walinya 13 serta variasi makanan yang diberikan, metode rekam nafsu makan/24 jam yang dilaksanakan setiap 3 hari sangat mengandalkan ingatan dari ibu/wali sampel sehingga sangat memungkinkan adanya bias.

\section{Kesimpulan dan Saran}

Tidak terdapat perbedaan bermakna skor nafsu makan dalam kelompok intervensi, kelompok kontrol, dan antara kelompok perlakuan dan kelompok kontrol

Dibutuhkan penelitian dengan jumlah sampel yang lebih besar, subjek yang berbeda dan metode penilaian asupan yang lebih sensitif, sehingga dapat memperkaya pengetahuan dan memberikan hasil yang komperhensif terhadap manfaat suplementasi ikan nila.

\section{Referensi}

1. Kementerian Kesehatan RI. Pusat Data dan Informasi. Kementerian Kesehatan RI.2016

2. Kementerian Kesehatan RI. Profil Kesehatan Indonesia 2015. 2016.

3. Khairuman, dan K. Amri. 2013. Budi Daya Ikan Nila. PT AgroMedia Pustaka. Jakarta.

4. Zai, H., Kusano, M., Hosaka, H., Shimoyama, Y., Nagoshi, A., et al. Monosodium l-glutamate added to a high energy, high-protein liquid diet promotes gastric emptying. Am J Clin Nutr; 2009. p. 431-5

5. Burrin, DG, Stoll Barbara. Metabolis fate and function of dietary glutamate in the gut. Am $\mathrm{J}$ Clin Nutr; 2009: 90. p.860-6(S).

6. Matthews, D.E., Campbell, R.G., The effect of dietary protein intake on glutamine, glutamate nitrogen metabolism in humans. Am J Clin Nutr; 1992;55. p. 963-70.

7. Kondoh, T., Mallick, H.N., Torii, $\mathrm{K}$., Activation of the gut-brain axis by dietary glutamate and physiologic significance in energy 
metabolism. Am J Clin Nutr; 2009;90 (supl) p.832S-7S

8. Kementerian Agama RI. Al-Qur'an dan terjemahannya, Bandung: $C V$ Penerbit JART, 2010.

9. Yuli hartati. Faktor-faktor Yang Berhubungan Dengan Konsumsi Ikan dan Status Gizi Anak 1-2 Tahun Di kecamatan Gandus Kota palembang Tahun 2005". Semarang :Program Studi Magister Gizi Masyarakat Program Pascasarjana Universitas Dipenogoro. 2006

10. Sri Hendrawati, Irfan Zidni. "Gambaran Konsumsi Ikan Pada Keluarga dan Anak PAUD RW 07 Desa Cipacing". Jurnal Pengabdian Kepada Masyarakat. Vol.1. No 2 April 2017: 101-106

11. Farah, Mellysa. Hubungan Pola Konsumsi Ikan dan Tingkat Pendapatan Orang Tua Dengan Status Gizi anak balita Keluarga Nelayan di
Kelurahan Pasir Nan Tigo Kota Padang 2016". Diploma thesis. ESkripsi Universitas Andalas. .2016 [cited 15 Nov 2019]. Didapat dari: URL

http://scholar.unand.ac.id/id/eprint/186 31

12. A.N. fathia Rachim, Rina Pratiwi. 2017. Hubungan Konsumsi Ikan Terhadap Kejadian Stunting Pada Anak Usia 2-5 Tahun. Jurnal Kedokteran Dipenogoro. Volume 6, Nomor 1, Januari 2017. Online: http://ejournals1.undip.ac.id/index.php/medico

13. Y.D.N Yendi, Ni Luh Putu Eka, N Maemunah. Hubungan Antara Peran Ibu Dalam Pemenuhan Gizi Anak Dengan Status Gizi Anak Prasekolah Di TK Dharma Wanita Persatuan 2 Tlogomas Kota Malang. Nursing News. Volume 2, Nomor 2 Tahun 2017.

Tabel 1. Karakteristik sampel penelitian

\begin{tabular}{lll}
\hline Variabel & Intervensi & Kontrol \\
\hline Umur (bulan) & $27.96 \pm 13.46$ & $29.26 \pm 12.75$ \\
Jenis kelamin & & 10 \\
Laki-laki & 15 & 9 \\
Perempuan & 8 & \\
\hline
\end{tabular}

Tabel 2. Perbandingan asupan energi dan protein pre dan post dalam kelompok intervensi

\begin{tabular}{llll}
\hline Variabel & pre & post & Nilai p* \\
\hline Energi & $627.16 \pm 58.71$ & $740.69 \pm 89.94$ & 0.301 \\
Protein & $21.1 \pm 2.3$ & $25.30 \pm 14.97$ & 0.236 \\
\hline \multicolumn{2}{c}{ *Uji Wilxocon } &
\end{tabular}

Tabel 3. Perbandingan asupan energi dan protein pre dan post dalam kelompok kontrol

\begin{tabular}{llll}
\hline Variabel & \multicolumn{1}{c}{ pre } & \multicolumn{1}{c}{ post } & Nilai p* \\
\hline Energi & $650.1 \pm 68.34$ & $654.94 \pm 77.33$ & 0.573 \\
Protein & $25.48 \pm 3.4$ & $25.06 \pm 14.01$ & 0.778 \\
\hline
\end{tabular}

*Uji Wilxocon 
Tabel 4. Perbandingan asupan energi dan protein pre dan post antar kelompok intervensi dan kontrol

\begin{tabular}{llll}
\hline Variabel & Intervensi & Kontrol & Nilai p \\
\hline \multicolumn{1}{c}{ Energi pre } & $627.16 \pm 58.71$ & $650.1 \pm 68.34$ & $0.810^{*}$ \\
Energi post & $740.69 \pm 89.94$ & $654.94 \pm 77.33$ & $0.587^{*}$ \\
Protein pre & $21.1 \pm 2.3$ & $25.48 \pm 3.4$ & $0.519 *$ \\
Protein post & $25.30 \pm 14.97$ & $25.06 \pm 14.01$ & $0.959^{* *}$ \\
\hline
\end{tabular}

*Uji Mann Whitney

**Uji T independen 